\title{
Axiological Paradigm of Understanding the Education Phenomenon as a Polyvector Discursive Construct: Harmony of Peace vs. Conflict of Military Interpretations ${ }^{[*]}$
}

\section{Eŭitim Olgusunu Çok Vektörlü Söylemsel Bir Yapı Olarak Anlamanın Aksiyolojik Paradigması: Barıșın Uyumuna Karșı Askeri Yorumların Çatı̧̧ması}

\author{
VIKTOR OGNEVIUK \\ Borys Grinchenko Kyiv University \\ OLENA ALEKSANDROVA (D) \\ Borys Grinchenko Kyiv University
}

\author{
ANDRIY TKACHUK \\ Defense Attaché Embassies of Ukraine \\ SVITLANA KHYRIPKO (D) \\ Borys Grinchenko Kyiv University
}

Received: oI.04.2020 | Accepted: 15.07.202I

\begin{abstract}
Education as a process is the dialogue of generations, and education as a result is the spiritual face of a man, community, era; it is formed under the influence of moral and spiritual values, which are the heritage of a particular cultural circle. Education is a qualitative and humanistic manifestation of extrapolation of "values of the environment" to "values of life experience", which together represent the "face" of a certain person (as well as people, nation, society, epoch). Self-education is a unique form of education (as an extraordinary embodiment of mature loneliness) and an original version of the embodiment of the heritage of the human existence. That is why the transition of society from industrial to information has been the impetus for the introduction of information technology in all spheres of public life, which, in turn, embodies distance learning as the most resonant educational and cultural phenomenon of postmodernity.
\end{abstract}

Keywords: Axiology, phenomenon, philosophy of education, self-education, values, educational discourse.

\footnotetext{
\Viktor Ogneviuk \& Olena Aleksandrova \& Svitlana Khrypko Borys Grinchenko Kyiv University, Faculty of History and Philosophy, Dep. of Philosophy 042I2, Kyiv, Ukraine $\mid$ s.khrypko@kubg.edu.ua

$\triangle$ Andriy Tkachuk

Defense Attaché Embassies of Ukraine in the Republic of Austria II8o, Vienna, Austria| tkachuk_ap@ukr.ne
} 


\section{Introduction}

Each coming century is the embodiment and personification of the century that passes: its values and pseudo-values; its ups and downs; its understanding of the world and attempts to interfere in the mystery of the eternal; its "men among men" and their antipodes. All this is engraved in historical memory, included in the mental experience, fiction and scientific literature. Each and every person is a representative of a particular ethnic group, nation, community - and, therefore, is the real embodiment of educational values produced by ethnopedagogy, national education systems, educational accents of a particular era. And these "accents" are always interesting, extraordinary, original and, of course, relevant in their own way for this period of history.

Axiological issues are eternally relevant. It is quite difficult to reflect on the problem of valuable, it requires a high philosophical culture, the ability to problematically analyze literary texts, to represent research findings scientifically correctly and to produce new knowledge. Each era produces its own system of value standards, and the educational space instantly responds to this proposal through educational and methodological developments, offering and placing its accents in the prototypes of the latter. Students, readers and researchers can only accept or not, agree or disagree with this factuality of the value problem.

The urgency of axiological knowledge is indirectly reinforced by our ambiguous past, the rather polar and complex circumstances of the present, and the very disturbing predictions about the future. This brings us to the following considerations: Education is the central pillar of life (in the unique-subjective aspect of understanding) and the primordial axis of existence (in the broadest sense of reflection and reasoning. It is the value content of education that is the projection of the buman look into the world, the vector of understanding, interpretation and vision. Thus, education (in the context of any understanding and interpretation) is a clear embodiment of the axiological spectrum of existence.

In the semantic-personalistic context, education is a person's spiritual face, which is formed under the influence of moral and spiritual values which are the common heritage of his cultural circle. Education is also a process of paren- 
ting, self-education, influence, i.e. the process of the development of individual. In the axiological dimension of understanding education, the main thing is not the amount of knowledge, but the combination of the latter with personal qualities, the ability to independently manage person's knowledge.

Axiology of education (pedagogical axiology) began to gain increased attention of researchers only in recent years. However, this does not mean that previously this philosophical direction was excluded from the research area. The problems of values, their comprehension and substantiation have never been outside of human existence, outside its the social dimension. Any philosophical school is based on a certain scale of values.

Ukrainian vector of problem actualization is the following: in addition to potentially interesting and positively resonant relevance as a philosophical direction, in many universities the axiology of education has acquired the status of a normative discipline taught at the master's level. We should agree that "Axiological education" as a philosophical direction and academic discipline embodies and represents a multi-vector functional content. Among the whole range of functions (informative, educational, communicative, etc.), the functions of correlation and extrapolation are of priority importance, because they determine the choice of living standards, guidelines, principles. Today, axiology of education is one of the most promising (and at the same time, one of the least researched) areas of philosophical knowledge, and as an academic discipline (given the priorities of university programs) is either a self-sufficient subject or content of the course "philosophy of education". It can also be stated that education (in any sense) cannot exist outside the value dimension.

In general, the values are the basis of the entire philosophical and educational heritage of human civilization, the entire culture and history of mankind. Values perform the function of long-term strategic life goals and key motives of life. They determine the moral principles and behavior. That is why any society is interested in the fact that people adhere to certain rules of conduct, that certain values and priorities of life are actualized, and that a person inevitably becomes the object of purposeful education. And the methodological system of education adopted in particular society is determined, in turn, by the prevailing system of values. Futurological trends in the 
axiology of education have serious prospects and levers of influence, because cardinal changes that have taken place in recent decades have intensified the search for new, vital values for the younger generation, their scientific understanding and substantiation, as well as methods of their assimilation into contemporary educational culture and practice.

The purpose of the article is to propose the author's version of interpretation, vision and perception of a priori relevance of axiological issues in general, as well as to reflect the phenomenon of education in the framework of comparative analysis with increased focus on the value vector of problem.

The core task of the work is the presentation of the education phenomenon as a value-polyvector discursive construct; the comprehension of the mental and national basis of educational axiology as a "value handwriting of social and intellectual existence"; drawing research parallels between axiological approaches in educational culture; establishing a connection between scientific and educational ideals and values.

\section{Methodology}

"Researching the role of education in the value system of sustainable human development ... is diversified between philosophers, politicians, economists, sociologists and educationalists, demonstrating little correspondence and lack of complex approach" (Ognevyuk, 20I8, p. I4). That is why, the set of complex theoretical and empirical methods of analysis, method of description and interpretation, comparison, synthesis and generalization, hermeneutic methodology and method of implication have been used to solve the tasks.

As a part of understanding the problem of methodology of research and decoding the value layer of a particular cultural era, the concept of $\mathrm{Yu}$. Sshaigorodskiy, who argued, comprehending the problem of value identification of the individual, that "there is another feature of values that $g i$ ves them special significance. Values are a kind of cultural "code". Its specificity is due to the fact that each culture generates its own, unique value system. This kind of "code" provides the process of cultural identification of the individual, people, nation, the development of national consciousness. The value "identification system" preserves the nation as the bearer of something unique, original. National and cultural 
specifics of the value system largely determine the features of national psychology. The hierarchy of national values was built over the centuries, determined by the entire history of the nation and adjusted by it through changes in values and guidelines depending on the time, a particular era of development. Obviously, it is the "cultural code" that underlies the statement that the path of civilization is not single-row but multi-row" (Sshaigorodskiy, 2002).

It makes sense to actualize the axiological methodology as a separate phenomenon. The problem of methodologies of axiological knowledge appears as a space for scientific discourse. Thus, the German philosopher Martin Heidegger, the author of the method of "thinking poetry" and the concept of "poetic speech", believed that axiology revolved in the world of logic, correlating values with meanings, certain fundamental principles. Thus, according to him, the method of axiology is a method of logical reasoning, argumentation. V. Ilyin, the contemporary researcher of axiological problems, completely disagrees with this position, arguing that in the methodological direction axiology got the fate of philosophy - to study the ascending preconditions, to analyze the relationship of the boundary with the one-order, self-similar. For this reason, the appropriate method of axiology is rational reconstruction, intensive theorizing, reflection (Ilyin, 2005).

Since the reflection of the axiological sphere is impossible outside the personal aspect of understanding, acceptance and perception, it seems appropriate to expand the layer of axiological methodology as follows:

- Intuitive methods (because a person does not always comprehend the realm of the valuable with the help of rational logic, but rather at the level of irrational inner sense of what is "significant" and what is only looks like it, but in fact is "superfluous", "alien", not worth the attention and time, therefore "not valuable").

- "Shock therapy", stress, extremal state, etc. (because quite often in the situation between "before" and "after", a person discovers the phenomenon of values, which are directed after what caused the extremal state in a person's life).

- Extrapolation of understanding of the values to one's own experience of "acquaintance" with them (one can think long about the value of life, 
but only after the "experience with death" life becomes a real perceived value, both in personal and universal context of understanding and perception).

- Comparative analysis of "valuable" and "invaluable" in the context of axiologically focused knowledge of certain problems and phenomena.

- Varieties of hermeneutic methodology (literal interpretation, moral interpretation, allegorical (symbolic) interpretation, analogous (mystical) interpretation, factuality of active and passive source of valuable information).

The methodological content of educational axiology undoubtedly includes the whole range of methods of classical axiology. However, taking into account separate educational-focused information, methods of communication, transfer of experience (both pedagogical and life one), interactive methods of intersubjective interaction, etc. acquire particular meaning.

\section{The Phenomenon of Axiology as the Essence of Philosophical Knowledge and the Surrounding Reality}

Human is not only an intelligent being, but also a value, ideological being. Human is not able to comprehend everything with his mind, but he is able to evaluate absolutely everything (Khrypko, 2009, p. I9). Human is able to evaluate and appreciate even the unknown, mysterious, incomprehensible, mystical, and so on. Rationality, intelligence is a capital, but not exhaustive characteristic. According to contemporary researchers, "The mind itself is neutral, technical in relation to existential themes. According to an identical reasonable scheme, you can build a nuclear boiler and a bomb, democracy and despotism. In the 'fateful minutes' the mind shifts away, requires equipment, passionate content, a certain content saturation..." (Ilyin, 2005, p. IO). Thus, general values, focused not only on the "achievable-effective", but also on the "humanitarian-desirable" are able to fill rational thinking with the highest spiritual quintessence.

"The system of moral principles, beliefs, and programs of social life is aimed at harmonizing relations in the system of 'man - society - nature'. Practical skills, abilities in the conditions of understanding and solving noosphere and humanistic problems, the 'behavioral' projection of the ideo- 
logical culture, reflecting the degree of internalization of the noohumanistic knowledge, values, ideas, thinking, feelings of the individual in everyday behavioral status, manifests itself in psychological, theoretical and practical readiness to carry out transformative activity according to the laws of beauty and harmony" (Khyzhna \& Lendiel-Siarkevych, 20I8, p. 80). Values are the mode, foundation, substantiation and result of a choice, the root and determinant of the phenomenon of choice as such. And a person is always in a state of choice, consciously or subconsciously.

Freedom of value choice is always for the individual, not for society. A person is valued by the set goals. Individuals who are the personified embodiment of certain values go through the entire history of mankind, because their names are included in the educational literature, remain in historical memory, archival documents and so on. They become an example, at the same time, they are harassed, people are proud of them and are afraid of them, they are loved and hated at the same time (Khrypko, 2009, p. II). "Personalities of the era" attract respect, admiration, shock, surprise, devotion and piety. "The heroes of their time" are capable of epoch-making valuefocused reforms. Any epoch, any community has always been concerned with the problem of the valuable, representing its version of the "right value-focused personality". Axiological incarnations run through the history of human civilization and, remaining in literary works, become a figurative embodiment of the object of admiration and imitation for future generations, as well as the object of philosophical reasoning, scientific research and future research discourses. And these tendencies are best shown by the axiologically focused academic, research and, especially, educational literature, which always reacts quickly to historical events, social sentiments, values, priorities and spiritual and moral condition of a particular era.

\section{Significance of Values in the "Extreme Situations" of Human Existence}

Human existence is the mystery of coming into this world, the unpredictability of the communicative and cultural factor of saturation of life as such, the encounter with loneliness (forced, voluntary, critical or mixed one) and the timid touch to the eternal question "what's next?" from the time of moving closer to entering the eternity. Life is a strange mixture of extraordinary moments, cruel boredom and sadness. Each stage of the life 
path (short or long) is characterized, given the circumstances of this period, by significant meetings, values and value accents of fate.

They can be different, even alternative in content and opposite in essence; eternal and temporary; real and imaginary, understandable and subconsciously unspoken, rationally delineated and intuitively perceptible, and so on. They are different. They are unique. And they are values, whatever focus they have and whatever they are interpreted.

Sooner or later, there comes a moment in everyone's life when the topic of values, the problem of their assertion or reduction, superficiality and depth, acquires special sharpness, special resonance. And such questions (search for answers to them) cover the whole mental essence of human being. Thus, value is what becomes the only thing that matters in the extreme situations of existence. The embodiment of the "only thing that matters" can be a specific person, news, feeling, a certain desire, high ground decision, state, life position, etc. These are the situations of life and the state of view of life when the concepts of truth, human, culture, justice, honor, dignity acquire a priority sound, and cognitive abilities approach the mystery of wisdom.

Situations, being different in content and result, actualize and bring to the surface of being values adequate to these situations. Such values for some time become primary, centric, become the dominant of life, the fateful accent, the axis of existence. The rational and the irrational are intertwined and focus on the point that unconditionally becomes the core value of this segment of life. There are "problematic" situations where it is enough to find a point of contact, voice the cause of the misunderstanding and solve the problem, but there are so-called "limit situation" (according to K. Jaspers), where what happens acquires the signs of "breaking" and acts on the verge of "possible" and "impossible", on the verge of patience, silence, morality and even existence. And until person is pushed beyond this edge, it is necessary to have time to take the only right step. The main thing is not to make a mistake in the direction of what this "step" is being done.

Thus, values are the embodiment of a qualitative and a priori choice under the circumstances, the content of which floats between extremes and "bottom". Valuable is that which prevents a person from "breaking down" 
and keeps him alive when his existence reaches the level of "extreme being" under the conditions that I. Franko described as "beyond the realms of possibility". And in this lies the significance of values, the content and role of which distinguishes the latter from the goals, priorities and so on. Acquiring irrational and even mystical characteristics, what has become a value is perceived as a life-affirming beginning of a new round of one's own destiny, as a source of impulses and aspirations, as a fundamental basis for a calm look into the mystery of the "tomorrow coming".

Values are the content of the Word from which life begins. After great highs and lows, history, humanity, civilization go forward, and people start it all again. The above statements embody the value of the well-known philosophical thesis that life is the greatest and strictest teacher, and in a purely academic context it is a representation of the recently popular concept of andragogy (adult learning), which “...is connected primarily with the need to study the educational needs of different categories and groups of the population" (Melnychenko, 2020) Thus, education (in the context of any understanding and interpretation) is a clear embodiment of the axiological spectrum of existence (from propagated values to forgotten or reduced ones).

\section{The Value Space of Education as a Subject of Philosophical Reflection}

Philosophy and education are phenomena that can be infinitely distant from each other in the field of theoretical and methodological reflection and at the same time close in values and mutual reflection. It is the axiological plane that covers and actualizes the common and the peculiar, the coincidence and the polarity of the educational and philosophical-cognitive spheres of the genesis of human civilization. Outside the human factor, the comprehension of anything from the world of philosophy, education and values loses its meaning and its factuality. It is the phenomenon of human as a sensible and thinking being that determines the significance of the philosophical and educational axiosphere of existence.

The variety of approaches to the study of the axiosphere generates a large number of criteria for the systematization of values. There are different points of view regarding their nature and understanding. In particular, the value is considered: 
- as an object that has a certain benefit and is able to meet a particular human need;

- as an ideal to which man aspires;

- as a rule that must be followed;

- as the significance of something for an individual or social group.

All these contexts are embodied in education (in terms of content, motivation, results and futurological forecasts). Value-focused conditionality of everyday and scientific knowledge gives axiology a special functional status of "priority guide" of human existence in general and professional choice in particular. Along with doctrinal axiology, this function is performed by a unique kind of thought discourse - the philosophy of education.

Values can be divided into spiritual and material, eternal and temporary, real and imaginary, past and present, stable and innovative, universal - social - personal, and so on. Values can be distinguished according to professional, priority, normative, prognostic and any other principle. But all the models look clear and competent only on paper. There are no schematically conditioned value pyramids in the life. And the whole educational space is a confirmation of that.

The differences that exist in the reflection on the educational values are unlikely to ever be resolved, even if a deep and comprehensive theory, focused on all aspects, facets and shades of the phenomenon of values, emerges.

It can be stated that the philosophy of education primarily considers the degree and nature of all phenomena in the educational process, namely:

- what is education itself (ontology of education);

- how it takes place and is obtained (logic of education);

- what is the nature and sources of educational values (axiology of education);

- what is the educational and communicative culture and what should be the behavior of the subjects of the educational process (ethics of education and educational management) or the latest version of this context (educology), which shows the universal nature of education (Frick, 2O2I); 
- what are and what should be the methods of communicative assistance to the educational process (methodology of education);

- a set of ideas that form the basis of an integrated approach to the establishment of education can be considered separately as the ideology of education.

It is the above contextual slice of the possibilities of understanding the value aspect of the philosophy of education that recalls the inseparable connection between the general philosophy and the philosophy of education, as well as their dualistic nature of mutual determination. After all, education (as a process of acquiring, improving and practical implementation of acquired knowledge) and philosophy (as a love of wisdom) simply cannot exist and develop apart from each other.

\section{Education as a Dualistic Unity of Process and Result}

Any definitions, interpretations and reflections on the essence of the educational phenomenon, anyway, are options for understanding education either as a "process of acquiring certain knowledge" or as "the result of involving this knowledge in the life". And the core, the basis of the essential value of education lies in this duality of the process and phenomenon. Before you have an education - you need to get it; before getting an education - you need to study; before studying it is necessary to determine for what future result the process of obtaining a certain (specialty) education takes place. The qualitative content of education is always the embodiment of certain reasons, priorities and meaningful results. Education represents the multi-vector beginning of receiving and equally multi-vector result of implementation. Education is always priority-determined, contextualized, value-driven.

\section{Education as a Value}

The opportunity to get an education has the value content in itself (because not everyone has this opportunity, unlike the right). The value content is, as already emphasized, the content of the process of obtaining education. And the fact of documented education (education as a result) already absorbs the significance and remarkability of education, is the embodiment of official recognition of the level of education and a demonstration of its projected quality. 
Education is something that can be perceived and interpreted:

- as a certain norm (normative value) of life in the process of familiarization and comprehension of the world;

- as what can be mentioned as the most significant period in life;

- as what brought a person as close as possible to the truth of knowledge and the mystery of the ideal;

- as a fact (process and phenomenon) which in itself is a value;

- as something that opens the way to professional life (knowledge plus a diploma);

- as something that gives an opportunity of self-development;

- as something that, one way or another, but really becomes a guide in life.

Education is something that people are proud of and that they are constantly improving, it is something that they have and the value content of which they constantly turn to. Education is what always "exists" (whatever its content is), it is a variant of property, which "cannot but be" a priori.

\section{Education as a Goal}

"Many people consider education and training as a kind of compulsion" - contemporary thinker and publicist O. Volya says - but the real "education requires efforts" (Volya, 2005). The desire to receive a certain education, certain knowledge; passion for learning - all these are potential determinants of achieving the highest priority goal of life - EDUCATION and ENLIGHTENMENT. And to achieve this goal, a person really needs to make a very serious effort. The "final line" cannot be drawn in the process of education. Education is a constant and endless process of cognition of the world, oneself, people, values and achievements of the civilizational progress of mankind.

Life constantly offers certain "lessons", life "teaches" and "tests" the acquired knowledge. Life is a very strict teacher. Education, in this context, appears as a goal of life and self-improvement, the embodiment of the life path of self-knowledge and self-reflection. The desire to live is the desire to find new, sometimes unexpected, facets of knowledge about the world around us in the broadest sense. Any education is a certain slice of 
knowledge about the world. And the enlightenment has always been not only the focus of the intersection of social, state, strata interests and priorities, but also the embodiment of personality-oriented curiosity and valuebased goals.

\section{Education as an Intellectual Phenomenon and the "Facet of Talent"}

Understanding the phenomenon of education outside the intellectual context and the factor of talent seems to be a wrong position, because the intelligence is the result of education as a process, and talent is "the drop of ability and the ocean of work" which is crystallized by the very content of a particular education. An intellectual is a person who is directed to the process of cognition, to the process of constant continuous education. Intelligence is always critical, but not always self-critical; almost always ironic, but not always humorous; sometimes cynical and somewhat skeptical. The best manifestation of a developed intellect is talent, the worst is snobbery (namely, intellectual snobbery).

Talent always has a human face, intelligence does not. Those people whose education is unobtrusive deserve deep respect. Talent is never imposed, at least because it is a talent. Talent cannot be trivial, it knows how to remain silent, knows how to step away.

Education is a trademark in life, is a tool of life affirming and a side of talent, but not its content. Talented people are talented in different ways, because talent cannot be repeated. Enlightenment offers to accept the inevitable death - and genius rebels against it. Educated people are close to discoveries, but discoveries are made by talents and geniuses.

\section{Education as a Way of Self-Realization}

One cannot but agree that education and creative activity begin only when a person decides what to do. The meaningful and qualitative result of the received education is shown particularly in the course of realization of own intellectual potentials in the field of professional activity and a way of life.

In the process of self-affirmation and self-knowledge, a person constantly turns to one's own existence, to the intrinsically motivated value paradigm of life. The latter is formed and adjusted with the help and partici- 
pation of educational institutions in general, and representatives of education in particular. Acquired knowledge (even if a person does not work in the specialty) will never be superfluous. Sooner or later, this or that information will "remind" of itself, will definitely come in handy, and in some cases will determine the lever of prime choice. Professional education can get a person away from one's own specialty (which is not, essentially, the embodiment of failure) and can suddenly emphasize the fidelity, correctness, unity of the professional path of self-realization.

Perceiving life and the world as a source of education (in the general sense), a person is constantly in the process of obtaining education, in the process of its improvement, contextual expansion and optimization. Human realizes himself through his own knowledge, with the help of the prism of the subjective division into "I know" and "I do not know"; "I do not understand", but "I will definitely find out", etc. Self-realization is a process of distinguishing one's own cognitive potentials, crystallization of educational-focused curiosity, as well as comprehension and rethinking of personal values and priorities. And on the way to self-realization (sometimes very contradictory and ambiguous), education plays not the last, but sometimes decisive role.

\section{Education as a Form of Intervention in the World}

Education gives a worldview, but often destroys it. Education shapes the worldview, but sometimes distorts it. Education corrects the worldview, but in some places breaks its integrity and unity. Education can open the world, but it can also cause a worldview crisis. Education can open the door to the world of the irrational, but can also break the harmony of worldview, depending on what is the education, who are educators. The tendencies of the latter determine both the version of understanding the world and the option of interfering in the mystery of world harmony.

A person may never leave one's own city, but with the help of educational information he can feel the spirit of other epochs, see the drama of historic turning points, learn about another culture, get acquainted with other traditions, etc. Thus, education as a process is a form of intervention in the world, and education as a phenomenon is a version of worldview and world perception. 


\section{Education as a Path to Self and the Embodiment of Loneliness}

The way of life is the way of self-knowledge, it is the way of self-actualization and self-destruction, it is the way to people and the way to oneself. Life is a source of education; the latter is a variant of knowing the meaning of life.

Educational information is not perceived as a whole, but rather selectively. A person hears that at the moment it is worth hearing in his understanding, what is urgently necessary or at least important for him. Any information, any situation is passed through one's own "self", through one's own value paradigm of life, through one's own priorities and principles. Every minute, every day a person discovers himself (first of all for himself), discovers his own potentials, his own secret, his own ambitions and his own doubts and sorrows. Life is always a spiritual teacher, and the higher education of the soul is conscience. The conscience voices the most objective assessment of certain words and actions, it is impossible to "make a bargain with" with conscience (if it really exists). Conscience is a thousand witnesses on the way to yourself.

Just as it is impossible to study for someone, so it is not possible to live someone else's life, to run away from one's own destiny - in other words, one cannot escape the inevitable consequences of one's own actions, words and deeds. Education opens up the possibility of finding one's personal uniqueness, however, personality is the only reality that we perceive and that we simultaneously process from within. All this brings us to a somewhat paradoxical idea about the leading role of the factor of loneliness in the process of acquiring education, because "loneliness can become a source of spiritual self-education, as well as life can be the only teacher. The way of life is the way of self-knowledge, self-actualization and selfdestruction, movement to people and the way to oneself. As the embodiment of experience and memory, education is self-education, because a person learns every day, every minute, every moment - alone with himself and the face of the world" (Aleksandrova \& Khrypko, 2020).

\section{Education as a Source of Wisdom}

"I know that I know nothing..." - these words of the most famous sage 
of antiquity are a standard of education, modesty and wisdom. The Socratic aphorism resonates with the opinion of contemporary domestic thinker O. Volya, who states: - "you get an education to know more, but having acquired knowledge, you are bitterly convinced that you know very little, and that which has opened up as knowledge is approximate and inaccurate" (Volya, 2005). Only wisdom is able to recognize the limitations of acquired knowledge, is able to emphasize this, and if necessary, to remain silent.

Wisdom is always modest and stupidity is the opposite. Wisdom is the knowledge of the necessary, not the incomprehensible. So, the art of wisdom is the ability to know what you should not pay attention at all. But "Neither art, nor wisdom can be achieved if they are not taught", Democritus said, which is why it is not enough to have wisdom, it is necessary to be able to use it competently and optimally. Only intelligent and educated people can hear and receive wise advice, wise thought, and wise silence, and Solomon was right about others, stating, "Do not cast your pearls before swine". The noblest words are not worthy of any attention if no one hears them. That is why a truly wise person is one who speaks only when he is listened to attentively, when what is said does not fall apart in silence, but reaches the value consciousness of the listeners, their attention and their essence. Only under such conditions a wise thought makes sense to be voiced.

Wisdom is the result of the experience of life, the latter is the source of education and self-education, and "The best education in the world is that got by struggling to get a living" (Wendell Phillips). Only that which has not been easy, has been obtained through resistance to circumstances and a certain suffering can become a value. Education is no exception, like wisdom. And, as M. Opitz claimed, “...The greatest wisdom is not always to be wise".

\section{Education as the Embodiment of Experience and Memory}

Memory always selectively leaves the most necessary and demanded information. Memory does not need any needless information. And memory never makes mistakes in its choice. The "choice", in turn, depends on experience (and the latter is more than different). That is why education (as a qualitative result) a priori cannot be the same, standard, stereotypical. 
Education is always individually-conditioned, priority-focused, value-defined and therefore qualitatively different.

As the embodiment of experience and memory, education is self-education under any circumstances. A person learns every day, every minute, every second. "Whatever you learn, you learn for yourself", as Petronius wrote. These words resonate with the opinion of our contemporaries - "University education, and especially self-education, gave ... not as much knowledge as beliefs" (O. Volya, 2005). We should agree that the greatest benefit is given to us by self-education and, with luck, masters - teachers. "Formal education will make you a living; self-education will make you a fortune”, as Jim Rohn wrote. Success, not least, depends on education, and "The educated person" - as stated by G. Simmel - "is one who knows how to find out what he does not know". The latter is the embodiment of scientific inquiry, so education is a step towards the world of science and this step is not the last, but sometimes the most important in life.

\section{Education as a Spiritual and Moral Pbenomenon}

"Education is where there is a belief in life, when the soul communicates with God", O. Volya wrote, emphasizing that "it is much easier to make the mind enlightened than to enlighten the soul. Human education and enlightenment begin in the womb and last from birth to death; and perhaps even after death the human soul passes through the higher cosmic educational orbits". Education is a complex embodiment of acquired knowledge and its representation in view of the moral priorities of a person. Educational information (for example, a lecture) is heard the same, but perceived differently. It is perceived in terms of personal priorities, morality, individual ethics, subjective criteria for understanding "good" and "evil", "possible" and "impossible" and so on.

A teacher who is perceived as a "man among men" as a "Spiritual Mentor" sometimes remains in memory as a "moral guide", and the meaning of his words and statements is mentioned again and again many years after graduation. In the same way, a certain separate thought, theory, hypothesis, etc. can be remembered, and can just not be remembered, but become core and contextual throughout life. "Values and beliefs partly concern the discourses through which teachers make sense of the situations in which they act (the cultural aspect of the practical-evaluative dimension), partly 
articulate their short-term and longer-term aspirations (the projective dimension), and partly stem from their personal and professional histories (the iterative dimension)" (Priestley et al., 2013).

Memory of student years can remain the best (and most ethical) memory in a person's life and destiny. That is why in relation to "Teachers with a capital letter" there are not just pietistic characteristics, but actually a "good memory", "worthy impression", "charitable memories". In other words, it is the moral context of the memory of the years of study and education.

The spiritual and moral context of the existence of education embodies the most relevant problem so far - the phenomenon of bullying and the value of inclusive practices in the educational and philosophical space of today's life (Dovha, 2020; Kolupaieva, 2009). It is difficult to disagree with researchers on inclusion in education, because the external "simplicity" of inclusive methods hides the real practical complexity of an inclusive teacher, whose work, a priori, cannot be a sham. The value of inclusive education lies in its practical content, which in turn embodies humanism, education, professionalism and love for "another microworld" (Dovha, 2020).

\section{Education as a Tool of Life}

Education in the broadest sense is a process of cognition of the world and human life and the discovery of its true meaning and mysteries. The content of the acquired education is a certain form of touching the phenomenon of life, it is a delineation of the way of understanding life and a certain professional slice of this comprehension and, so to speak, "living". Education is a specific emphasis in the process of cognition and formation of one's own journey through life. Education is a way of growing up and gaining mental maturity. As Ernest Legouvé wrote: "The purpose of education is to teach our children to do without us".

\section{Education as a Way of Life}

Education creates a certain image of a man, forms the very spiritual face, outlines the vector of personal view of the world and place of a man in the world. The specificity and content of the acquired education become the guide that forms life's journey. For example, pedagogical education under any conditions will be manifested in the nature of responding 
to certain life circumstances, and the latter in turn will never deprive a person of a certain pedagogical particularity in the process of making certain decisions.

Thorough quality education is able to form a strong life line. With a good education, professional life cannot "be completely unsuccessful". Education received "hastily", "in the wrong institution" and "not in the right" profession can sometimes play a fatal role in human life, break the life line, the priorities of one' own "self" or cause the loss of this "self".

\section{Education as a Reflection of Communicative and Information Culture}

In today's globalized world, the information sphere is one of the most comprehensive. Information has gained supreme importance in the modern scientific and philosophical parlance (Dutta, 20I6). Education as a reflection of social transformations is constantly changing due to emerging challenges of today. New forms of education are formed to meet the needs of people living at the intersection of real and virtual worlds.

The COVID-I9 pandemic has intensified the use of information technology for distance learning at all levels of education, however, despite the considerable variability of platforms and software and despite the wide range of opportunities, the question of the value perception of modern education remains open. Despite active development of new methods of computerized education, such as gamification (Zahedi et al., 202I), the use of videogames in education, etc. (Horban et al., 2O2O), their implementation, the question of value transformation remains unanswered. The informatization and virtualization of society shifts the vector of values from real to virtual. At the same time, information becomes an even greater value, which requires the formation of a new social value paradigm. The global change in the transformation of universities, their priorities and values, is necessary, especially in our country (Ogneviuk, 2018).

Education as a Tool for the Harmonization of Hybrid Conflicts as the Embodiment of the Discourse of Interpretations

This context is the most modern cut of the postmodern world of conflicts and their mixing. It is the analytical component, which is the embodiment of a particular level of education, moral and value content of education becomes the most powerful weapon in hybrid wars. The latter not only 
correct the map of the world, but also change the emphasis of historical education, mix national values and priorities in educational programs, reduce ethno-oriented criteria of education, "rewrite" history as such, etc.

There are two asymmetric modes of existence of war - physical and discursive. In the military (material) dimension, any military confrontation in general (and the Russian-Ukrainian conflict in particular) is localized, while the discourse of this hybrid war has become global. The interpretive component of hybrid warfare is implemented through discursive verbalsemiotic means. During hybrid warfare, conflict of interpretations is used as a weapon along with other non-military components of hybrid action.

The combination of different military and non-military means is, to a large extent, the embodiment of certain educational programs, education as a result and as the embodiment of the private "self". The specificity of education can act as a counterculture to the logic of common sense and, as a result, can lead to interpreting the invader as a liberator and so on. As an example, the vagueness and uncertainty of the nature of modern conflicts is reflected in the multiplicity of terminological names for a wide range of phenomena:

- bybrid war,

- conflicts in the "gray zone",

- gray wars,

- unrestricted conflicts and others that aim to distinguish modern wars from traditional or conventional types of armed conflicts.

What it is - intellectual discourse or pseudo-analytics, enlightenment or its illusion? The negative result of such scattered terminology, according to experts, is the following: the fact of excessive use of additional terminological "stickers" for the current conflicts, their obsessive repetition outside the in-depth reflection on the core of the problem makes some experts doubt whether to talk about new forms of warfare, and perhaps it is more correct to consider the latest conflicts as the use of classic methods of force and strategies, the effectiveness of which is enhanced by the use of advanced technologies in combination with the conscious use of vulnerabilities of Western security structures (Echevarria \& Antulio, 20I6).

The mixing and asymmetry of the discursive and material modes of 
hybrid confrontation is more than a marked emphasis on the military problem that is being talked about but not solved. Instead, the educational and intellectual discourse related to the events in Ukraine has acquired a global scale, while varying significantly at the local (Ukrainian internal), interstate (Russian-Ukrainian) and global levels. These three main dimensions of the information discourse of war are related to different, usually controversial interpretations of events.

The informational and semantic specificity of the Russian-Ukrainian hybrid war in 2014-2016, in comparison with the previous conflicts, which were related to wars of this type is the following:

I. the intensity and breadth of coverage of the audience of information influences, which has acquired a global dimension (internal (Ukrainian), interstate (Russian-Ukrainian), international),

2. the systematic and comprehensive use of media;

3. the creation of a new discourse of war, aimed at the destruction of existing and the formation of new interpretive and semantic mechanisms of perception of reality (Horbulin, 20I7, p. 4I).

The educational vector of the clash of interpretations is sometimes a quasi-analytical dissonance of values. The conflict over the dominance of interpretive models of the postmodernity is the most noticeable cut of the epistolary genre (both scientific-analytical and everyday populist). Conflict of interpretations becomes a separate type of information weapon. That is why the interpretation of hybrid warfare as "not exactly a war" is quite common. This understanding of the content of war is beneficial primarily to the aggressor. The victim of the conflict in some way finds himself in the conditions of multidirectional loneliness (imposed isolation, alienation, etc.) (Aleksandrova \& Khrypko, 2020). The state can also be lonely, especially at the beginning of the legitimization of a military conflict. Educational programs in history, literature, and ethics with eternal "peaceful values" immediately become "outdated" and lonely in their own way, because reality contradicts them too aggressively.

The concept of hybrid warfare is based on a cognitive frame that remains partly undefined. The clash of narratives with opposing versions of events is a certain information front, where the "lecturer" plays almost the 
main role. The value content of the "information front" is significantly reflected in the thoughts, beliefs and actions of the population of both the countries in conflict and the world. The success of the application of the "information front" is due to the use of various technologies to manipulate the consciousness of society. The interpretive component (which embodies the values and education of its respondents) can, not surprisingly, be crucial in the concluding plane of a conflict.

\section{Conclusion}

It is appropriate to conclude that in the very fact of turning to the language of values (for example, in the expressions of such a general plan as "value judgments", "value categories", "logic of evaluations", "value systems", "value-based approach", "value research", "general theory of value", etc.), the specific direction and peculiarity of thinking should be noted and stated. And this thinking is value-conditioned and value-focused. In view of the above, it can be stated that the problem of axiology is deeply codetermined with the topic of axiological linguistics. The philosophical problem should be covered in philosophical language. An educator (teacher, tutor, scientist) always speaks and writes in his own language of values. And this language must be simple and brilliant at the same time.

The status of axiology in the content of philosophical significance is directly proportional to the model of coverage of a problem-focused topic. In turn, the value status of a philosophical problem is a reflection of the level of interest and clarity of the content of this problem in the field of human interests, priorities, desires and aspirations.

The axiology of education is the alpha and omega of the philosophy of education. The axiological module is the core of both philosophical theory and educational practice. The axiosphere is the source, the content, the essence of the results of any educational activity in life of each teacher. Particular educational projects are implemented on the basis of a certain value platform. Based on a set of certain values, affirmative or critical decisions are made about reforming the education system. The priority of certain values (national or European, ethnic or geopolitical, etc.) determines the vector of choice in the content of educational policy of the state. 
In the educational plane of implementation, such issues are always a problem of value-focused choice. The axiology of education is central in the content of the general "philosophy of education", is determinative in relation to the "methodology and ontology of education", is a potential projection of "ethics of education" and, of course, is a vector paradigmatic basis of "logic of education".

From a futurological point of view, it makes sense to state that any epoch is an epoch of choice, any generation considers itself to be a "generation of transition", a generation of historical turning point (often presented in the context of "lost generation"). There is no doubt that other generations of people, not only our, experienced the breaking moments of history, felt fear of the state between "before" and "after", experienced a sense of crisis of the era, and therefore were faced with the need to choose and develop a new world order. Any education is a way to itself and the embodiment of loneliness, because "Life is a work of loneliness, it is the ideas of the inner voice recorded on the stone tablets of memory. Loneliness is a spiritual and ideological handwriting of a certain person" (Aleksandrova \& Khrypko, 2020). Both extraordinary-unique are the scars, handwriting of loneliness and education, enlightenment and one's own values. Education is a person's spiritual face, and education is a trademark.

Both the history of problematic scientific discourse and the realities of today's world show that axiological topics are not only in the focus of attention of professionally interested specialists and researchers, but are one of the most resonant and relevant in all sectors of society. Thus, the axiology of education has an interesting and very serious scientific potential, and given the peak of resonance of educational-innovative waves of today, we can predict the inevitability of research accentuation and actualization of axiological issues in the future.

\section{References}

Aleksandrova, O., \& Khrypko, S. (2020). Solitude as a Problem of Human's Mature Choice. Beytulbikme. An International of Philosophy, Io(3), 77I-785.

Dovha, Kh. (2O20). Fenomen Bulinhu ta Tsinnist Inkliuzii v Osvitnofilosofskomu Prostori Sohodennoho Ukrainskoho Buttia [The Phenomenon of Bullying 
and the Value of Inclusion in the Educational and Philosophical Space of Today's Ukrainian Life]. "Kyiv Philosophy Studies-2020": All-Ukrainian Scientific Conference with International Participation. Kyiv, Borys Grinchenko Kyiv University: May, 19

Dutta, S. (2016). Philosophy of information: range and tenets. Annals of Library and Information Studies, 63(2), 9I-IO2.

Echevarria, II, \& Antulio, J. (2016). Operating in the Gray Zone: An Alternative Paradigm for U.S. Military Strategy, U.S. Army War College Press.

Frick, T.W. (202I) Educology Is Interdisciplinary: What Is It? Why Do We Need It? Why Should We Care? Intersections Across Disciplines. Educational Communications and Technology: Issues and Innovations (Ed. Hokanson B., Exter M., Grincewicz A., Schmidt M., Tawfik A.A.). Springer, Cham.

Horban, O., Martych, R., \& Maletska, M. (2020). Phenomenon of Videogame Culture in Modern Society. Studia Warmińskie, 56, I23-135. https://doi.org/IO.3I648/sw.43I4

Horbulin, V.P. (Ed.). (2017). Svitova hibrydna viina: ukrainskyi front [World Hybrid War: Ukrainian Front], NISS.

Ilyin, V. (2005). Axiology [Axiology]. Moscow

Khrypko, S. (2009). Aksiolobiia osvity v sferi mizh predmetnoho dyskursu: tsinne, mentalne, naukove [Axiology of education in the field of interdisciplinary discourse: valuable, mental, scientific]. Kyiv, National Pedagogical Dragomanov University

Khyzhna, O., \& Lendiel-Siarkevych, A. (20I8). Peace Education as Arts Education: In Search of New Strategies. Philosophy and Cosmology, 21, 74-83.

Kolupaieva, A. (2009). Inkliuzyvna osvita: realii ta perspektyvy: monohrafiia [Inclusive education: realities and prospects: monograph]. Kyiv, SammitKnyha

Melnychenko, O.V. (2020). Andragogical Principles of Adult Educationand Providing the Quality of Continuous Pedagogical Education. Pedagogical Education: Theory and Practice. Psychology. Pedagogy, № 33 (I), 24-30

Ogneviuk, V. (20I8). Ukrainian University at the time of exponential development. Educological Discourse, I-25. https://doi.org/IO.28925/23I2-5829.2OI8.I-2.I452 
Ognevyuk, V. (20I8). Developing education as an opportunity for medium-developed countries in the context of innovative revolution: a case of Ukraine. Education: Modern Discourses, I, I3-23.

Priestley, M., Biesta, G., \& Robinson, S. (20I3). Teachers as Agents of Change: Teacher Agency and Emerging Models of Curriculum. In M. Priestley \& G. Biesta (Eds.), New Trends in Curriculum Policy and Practice. London: Bloomsbury.

Sshaigorodskiy, Yu. (2002). The Value Component in the Inter-Cultural Communication. Ukrainskyi sotsium, I'2002, 4I-48

Volya, O. (2005). Aforyzmy ta dumky: Entsyklopediia zhyttia [Aphorisms and thoughts: Encyclopedia of life]. Kyiv.

Windelband, W. (1995). Izbrannoye: Dukh $i$ istoriya [Featured: Spirit and History]. Moscow.

Yatsenko, A.Y., \& Trushliakova, A.B. (2015) Andragogy in multicultural environment. Navchalno-naukovyi humanitarnyi instytut NUK, Issue 8, I4-I8.

Zahedi, L., Batten, J., Ross, M. et al. (202I). Gamification in education: a mixedmethods study of gender on computer science students' academic performance and identity development. Fournal of Computing in Higher Education.

Öz: Bir süreç olarak eğitim nesiller arası diyalogdur ve sonuç olarak eğitim bir insanın, toplumun, çăgın manevi yüzüdür; belirli bir kültürel çevrenin mirası olan ahlaki ve manevi değerlerin etkisi altında olușur. Eğitim, birlikte belirli bir kișinin (insanlar, ulus, toplum, çağın yanı sıra) "yüzünü” temsil eden "çevre değerlerinin” "yașam deneyimi değerlerine" ekstrapolasyonunun niteliksel ve insancıl bir tezahürüdür. Kendi kendine eğitim, benzersiz bir eğitim biçimidir (olgun yalnızlığın olağanüstü bir düzenlemesi olarak) ve insan varolușunun mirasının düzenlemesinin orijinal bir versiyonudur. Bu nedenle, toplumun endüstriyelden bilgiye geçiși, bilgi teknolojisinin kamusal yaşamın tüm alanlarına girmesi için itici güç olmuștur ve bu da, postmodernitenin en yankılanan eğitimsel ve kültürel fenomeni olarak uzaktan öğrenmeyi içermektedir.

Anahtar Kelimeler: Aksiyoloji, fenomen, eğitim felsefesi, kendi kendine eğitim, 
değerler, eğitim söylemi.

$\left[{ }^{*}\right]$

The authors would like to express their sincere gratitude to the Embassy of Ukraine in the Republic of Austria for the support of preparing this article. 